Prophetic: Professional, Empathy and Islamic Counseling Journal

Vol. 2, No. 2, Desember 2019, hlm. 203-212

e-ISSN : 2685-0702, p-ISSN : 2654-3958

Tersedia Online di http://syekhnurjati.ac.id/jurnal/index.php/prophetic

Email: prophetic@syekhnurjati.ac.id

\title{
Media Photovoice untuk Mengurangi Bullying pada Siswa Kelas VIII Di MTs Negeri 1 Kota Cirebon
}

\author{
Hazmi Zulpikar \\ MTs Negeri 1 Kota Cirebon \\ hasmizulpikar84@gmail.com
}

\begin{abstract}
Abstrak
Salah satu bentuk kekerasan yang sering terjadi di kalangan pelajar adalah bullying. Begitu pula yang terjadi di MTs Negeri 1 Kota Cirebon. Disana masih sering terjadi yang namanya saling ejek nama orang tua, mengejek bentuk badan, dan lain sebagainya. oleh sebab itu penelitian ini bertujuan untuk mengurangi bertambahnya perilaku bullying pada siswa kelas VII MTs Negeri 1 Kota Cirebon. Penelitian ini menggunakan media photovoice dirasa paling tepat untuk mengurangi perilaku bullying siswa. Media photovoice sebagai dirasa paing tepat untuk mengatasi masalah tersebut. Sehingga photovoice diambil sebagai media untuk mengurangi perilaku bullying. Metode yang digunakan dalam penelitian ini adalah kualitatif dengan menggunakan pendekatan partisipan. Penelitian ini dilaksanakan secara kolaboratif dengan guru BK. Teknik pengumpulan data menggunakan observasi, wawancara. Hasil dari penelitian ini menunjukkan bahwa photovoice mampu mengurangi perilaku bullying siswa seperti cyber bullying dan physical bullying.
\end{abstract}

Kata Kunci: Photovoice; Bullying; Siswa.

\section{PENDAHULUAN}

Kekerasan yang sering dilakukan oleh para siswa pada zaman sekarang lebih dikenal dengan istilah bullying. Baik itu kekerasan secara fisik maupun secara verbal. Menurut Coloroso (2003:4) bullying adalah tindakan bermusuhan yang dilakukan secara sadar dan disengaja yang bertujuan untuk menyakiti seperti menakuti memalui ancaman agresi dan menimbulkan teror. Termasuk juga tindakan yang direncanakan maupun yang spontan, bersifat nyata atau hampir tidak terlihat, dihadapan seseorang atau di belakang seseorang mudah untuk diidentifikasi atau terselubung dibalik persahabatan, dilakukan oleh seorang anak atau kelompok anak.

Penyebab terjadinya bullying itu sendiri sangat banyak, seperti adanya rasa ingin berkuasa, akibat kurang perhatian dari orang sekitar,pelaku pernah menjadi korban kekerasan, akibat sering berkelahi, akibat meniru tindakan kekerasan dari film atau game, dan lain sebagainya. Bullying itu sendiri banyak macamnya, mulai dari bullying secara 
fisik, sosial, elektronik, sampai bullying verbal. Bullying secara fisik artinya kekerasan yang dilakukan dengan kontak secara fisik yang menyebabkan sakit seperti luka, cidera, dan lain sebagainya. Bullying sosial merupakan jenis bullying berupa pelemahan harga diri korban secara sistematis melalui pengabaian, pengucilan, dan penghindaran. Bullying elektronik (cyberbullying) merupakan bullying yang dilakukan pelaku melalui sarana elektronik seperti komputer, handphone, internet, website, chatting dan lain sebagainya. Bullying verbal yaitu bullying yang dilakukan dengan tindakan berupa celaan, fitnah, julukan nama, kritikan kejam, penghinaan, pernyataan-pernyataan yang bernuansa ajakan seksual atau pelecehan seksual, teror, gosip, dan lain sebagainya.

Perilaku bullying itu sendiri kini sudah sangat sering kita dengar terutama di kalangan anak sekolah. Seperti yang terjadi di MTs Negeri 1 Kota Cirebon bullying kerap kal terjadi. Hampir semua tipe bullying ada di sana, mulai dari bullying verbal yang paling dominan, bullying sosial, fisik, dan juga cyberbullying. Tentu saja banyak sekali dampak negatif dari kegiatan bullying ini. Oleh sebab itu sebagai pendidik, kita harus mengetahui cara yang paling efektif untuk mengurangi dan mencegah perilaku bullying ini semakin banyak.

Menurut Moh Khoerul Anwar, konselor profesional memerlukan langkah-langkah yang sistematis dalam menghadapi cyber bullying. Adapun langkah-langkahnya sebagai berikut: (a) konselor sekolahpun harus mampu "melek teknologi/ internet"; (b) konselor sekolah mampu menjaring akses media sosial yang siswa miliki; (c) konselor berperan aktif dalam media sosial yang siswa miliki; (d) konselor mengarahkan siswa agar menggunakan media sosial seperlunya; (e) konselor membimbing siswa agar mampu memfilter dirinya dalam menggunakan media sosial; dan (f) konselor profesional memiliki hubungan yang harmonis dengan berbagai siswa di media sosial. Dengan beberapa langkah ini, kejadian cyberbullying akan terminimalisir dan dapat tertangani dengan baik.

Ada banyak media yang bisa digunakan untuk mengatasi perilaku bullying ini, salah satunya yaitu dengan mengaplikasikan media photovoice. Photovoice merupakan sebuah penelitian tindakan partisipatif (PAR). Menurut Wang teknik photovoice ini sering digunakan oleh banyak peneliti dalam penelitian-penelitian yang erat kaitannya dengan menumbuhkan suatu kesadaran dan kepedulian terkait permasalahan dalam kehidupan (Handoyo, 2013:6).

Penggunaan photovoice untuk mengatasi perilaku dan tindakan bullying itu sendiri memang belum banyak. Namun banyak juga para peneliti menggunakan photovoice sebagai media penelitiannya. Pertama, penelitian yang dilakukan oleh Ernie Ulfiatun jurusan Bimbingan dan Konseling Islam dari UNY dengan judul "Peningkatan Empati dengan Teknik Photovoice". Perbedaan penelitian penulis dengan penelitian ini adalah pada aspek yang diteliti. Penulis meneliti tentang perilaku bullying sedangkan penelitian Ernie mengenai sikap empati. Bullying dan empati tentu dua hal yang sangat berbeda. Empati adalah salah satu sikap positif yang harus ditingkatkan sedangkan bullying adalah salah satu sikap negatif yang harus dihilangkan. Dan disini tujuan penelitian penulis tentunya adalah untuk mengurangi dan atau menghilangkan perilaku bullying siswa. 
Kedua, penelitian milik Made Diah Lestari dkk dari jurusan psikologi Universitas Udayana dengan judul "Kesehatan Seksual dan Reproduksi Serta Fasilitas Kesehatan di Lokasi Prostitusi: Community Based Participatory Research dengan Photovoice pada Pekerja Seksual di Gunung Lawu, Bali." Perbedaan penelitian penulis dengan penelitian ini adalah pada aspek yang diteliti dan juga metode penelitiannya. Penulis meneliti tentang perilaku bullying dengan metode observasi, wawancara, dan dokumentasi. Sementara itu, penelitian Made Diah mengenai pekerja seksual dengan metode penelitian CBPR (Community Based Participatory Research). Kedua penelitian ini hampir sama yaitu untuk mensosialisasikan dampak buruk dari suatu kegiatan, akan tetapi kegiatan yang diteliti adalah berbeda. Penelitian Made mengenai kegiatan prostitusi di Bali sedangkan penelitian penulis mengenai bullying di MTs Negeri 1 Kota Cirebon.

Melihat contoh kedua penelitian di atas yang memanfaatkan photovoice sebagai sarana penelitiannya dan berhasil semakin membuat penulis yakin bahwa penggunaan media photovoice untuk mengurangi perilaku bullying di MTs Negeri 1 akan berhasil. Photovoice untuk mengurangi bullying tentu saja sangat penting dalam lingkup bimbingan dan konseling Islam. Dimana nantinya media photovoice ini dapat diperlihatkan kepada para siswa, agar mereka memahami apa saja yang termasuk perilaku bullying, dampak dari perilaku bullying, dan tentu saja tips-tips untuk mengurangi perilaku bullying. Apabila para siswa sudah memahami ketia hal itu tentu kegiatan belajar di sekolah menjadi lebih aman dan menyenangkan. Secara psikologis mereka menjadi tenang dan mampu melaksanakan tugas perkembangan baik secara fisik, psikis, maupun rohani.

\section{METODE PENELITIAN}

Penelitian dalam penulisan ini adalah penelitian lapangan yaitu penelitian dengan pengambilan data dari beberapa subyek sebagai informasi informasi mengenai latar belakang keadaan permasalahan yang akan diteliti. Cara yang digunakan dalam penelitian lapangan ini adalah observasi, dokumentasi dan wawancara. Penelitian ini bersifat kualitatif yaitu prosedur penelitian yang menghasilkan data deskriptif, karena data yang dianalisis tidak untuk menerima atau menolak hipotesis, melainkan hasil analisis itu berupa deskriptif dari gejala-gejala yang diamati, yang tidak selalu berbentuk angka-angka atau korfisien antar variabel.

Subyek penelitian adalah sumber data utama dalam penelitian, yaitu yang memiliki data mengenai variabel yang diteliti. Sesuai dengan permasalahan penelitian yang dipaparkan tersebut, maka subjek penelitian ini adalah Guru Bimbingan Konseling dan Siswa MTs Negeri 1. Guru Bimbingan dan Konseling sebagai guru yang memahami karakteristik dan kepribadian para siswanya, serta memantau kegiatan sehari-hari siswa. Beberapa siswa sebagai anak-anak yang dirasa mampu untuk memerankan diri sebagai anak korban bullying dan pelaku bullying. Diambil dari beberapa siswa kelas VIII, yang pada dasarnya merupakan siswa yang normal dalam artian bukan pelaku maupun korban bullying. Sedangkan objek adalah permasalahan-permasalahan yang menjadi sentral dalam 
suatu penelitian. Dalam penelitian ini objek penelitiannya adalah perilaku bullying siswa, yaitu perilaku melukai seseorang baik melalui kata-kata maupun kekerasan fisik, seperti mengejek, memukul, mencibir, dan lain sebagainya.

Metode pengumpulan data pada ini adalah dengan menggunakan observasi, wawancara, dan dokumentasi. Observasi dapat diartikan sebagai pengamatan dan pencatatan dengan sitematika fenomena-fenomena yang diteliti. Wawancara atau interview merupakn alat pengumpulan data yang sangat penting dalam penelitian yang melibatkan manusia sebagai subjek sehubungan dengan realitas atau gejala yang dipilih untuk diteliti.

Kegiatan bimbingan yang dilakukan terkati media yang diteliti berupa photovoice. Semua ini didapat dari subjek peneliti yaitu Guru Bimbingan Konseling dan siswa tentang photovoice. Untuk menghindari kehilangan informasi, maka peneliti meminta izin kepada subjek untuk mencatat hasil penelitian. Sebelum dilangsungkan wawancara mendalam, peneliti menjelaskan atau memberikan sekilas gambaran dan latar belakang secara ringkas dan jelas menenai topik penelitian. Dokumentasi adalah metode pencarian data mengenai hal-hal yang berupa catatan, transkrip buku, surat kabar, majalah, prasasti, notulen rapat, leger, agenda dan sebagainya. Dalam penelitian ini berupa foto yang mengambarkan kegiatan.

\section{HASIL DAN PEMBAHASAN}

Penelitian dilakukan di MTs Negeri 1 Kota Cirebon ini mengenai media photovoice untuk mengurangi perilaku bullying. Photovoice merupakan media yang digunakan untuk memberikan informasi mengenai hal-hal sederhana yang ada di sekolah. Biasanya media ini digunakan dalam layanan klasikal, misalnya saat anak-anak diberi pemahaman tentang materi kerjasama. Guru BK akan menggunakan media tersebut untuk memberitahu siswa bahwa kerjasama itu penting. Bentuk media ini adalah berupa gambar siswa yang sedang bermain ular tangga atau permainan lainnya yang membutuhkan kerjasama. Kemudian dalam gambar tersebut juga diselipkan beberapa kata-kata mengenai kerjasama, seperti pada contoh berikut.

1. Melalui kerjasama kelompok akan membuat kita lebih bersemangat

Dalam menyelesaikan masalah kita pun perlu kerjasama kelompok, saling terbuka, saling membantu dan memberikan dukungan moral.

2. Permainan secara kelompok

Media ini membuat kita dapat menunjukkan sejauh mana kita mampu kerjasama dalam mengerjakan tugas dan menjadikan tugas tersebut terasa ringan, cepat selesai dan tidak bosan.

Ada beberapa penelitian yang terkait dengan penelitian ini. Jurnal Ernie Ulfiatun dengan judul "Peningkatan Empati Melalui Teknik Photovoice pada Kelas X Jurusan Kriya di SMK Kalasan" yang berisi tentang penggunaan teknik photovoice yang dapat meningkatkan sikap empati siswa berdasarkan skor skala empati. Berdasarkan hasil wawancara dan observasi perubahan yang nampak pada siswa setelah diberikan tindakan 
yakni, siswa terlihat lebih peduli dengan siswa yang lain baik secara verbal maupun nonverbal dan bisa memahami orang lain. Perbedaan dari penelitian ini yaitu terletak pada subjek dan objek serta aspek yang diteliti. Subjek dari jurnal ini adalah siswa kelas X untuk meningkatkan empati siswa, sedangkan subjek dari penelitian penulis adalah 3 siswa dan 2 siswi untuk mengurangi perilaku bullying. Objek penelitian jurnal ini adalah pelaksanaan teknik photovoice di kelas X Jurusan Kriya di SMK Kalasan, sedangkan objek dari penelitian yang penulis lakukan adalah pelaksanaan teknik phoovoice di MTs Negeri 1 Kota Cirebon.

Penelitian lain yang terkait photovoice adalah penelitian milik Made Diah Lestari dkk dari jurusan psikologi Universitas Udayana dengan judul "Kesehatan Seksual dan Reproduksi Serta Fasilitas Kesehatan di Lokasi Prostitusi: Community Based Participatory Research dengan Photovoice pada Pekerja Seksual di Gunung Lawu, Bali." Hasil dari penilitian ini yaitu Perbedaan penelitian penulis dengan penelitian ini dinilai mampu membantu mereka mengutarakan pikiran dan perasan mereka.Perbedaan penelitian ini ada pada aspek yang diteliti dan juga metode penelitiannya. Penulis meneliti tentang perilaku bullying dengan metode observasi, wawancara, dan dokumentasi. Sedangkan penelitian Made Diah mengenai pekerja seksual dengan metode penelitian CBPR (Community Based Participatory Research).

Penelitian ketiga yaitu dari jurnal Joyce A. Bredesen, DNP, RN dan Marcia S. Stevens, DNSc, RN yang merupakan profesor dan asisten profesor dari School of Nursing Metropolitan State University yang berjudul "Using Photovoice Methodology to Give Voice to the Health Care Needs of Homeless Families". Penelitian tersebut melibatkan 13 tunawisma yang tinggal di St. Paul, Minnesota. Mereka disediakan kamera dan diminta untuk mendokumentasikan kehidupan sehari-harinya. Mereka diarahkan untuk memotret gambar yang positif atau negatif yang dapat mempengaruhi kesehatan pribadi atau keluarga mereka. Hasil dari penelitian tersebut menyatakan jika ke tiga belas tunawisma tersebut adalah tentang kehidupan pangan mereka. Mereka makan dua kali sehari dan keluarganya yang lain diberi makan tiga kali sehari dari penampungan. Tunawisma tersebut berkata jika anak-anak mereka lapar namun tidak bisa menyediakan makanan. Sembilan dari peserta berbicara tentang kurangnya pilihan makanan, dan tujuh dari kelompok ini menyatakan bahwa kurangnya makanan bergizi yang menjadi masalah bagi para tunawismwa tersebut. Dari penuturan para tunawisma tersebut maka dapat dilihat bahwa mereka menyuarakan segala bentuk kenyataan yang terjadi dalam kehidupan tunawisma sangat tidak baik, khusunya kesehatan.

Peneltian keempat yaitu dari journal dari Nadia Rania, Laura Migliorini, Paola Cardinali, dan Stefani Rebora mahasiswi University of Genoa, Italia yang berjudul "Dare un volto ai processi di immigrazione e integrazione: l'uso di fotovoice con i giovani adulti italiani" memberikan wajah untuk imigrasi dan proses integrasi: penggunaan photovoice dengan orang dewasa muda Italia. Penelitian ini menggunakan photovoice untuk menyelidiki perspektif mayoritas pemuda di Italia mengenai proses imigrasi dan integrasi. 
Para peserta adalah 99 dewasa muda Italia tinggal di dua daerah barat daya Italia. Gambar yang dihasilkan oleh orang dewasa muda dan diskusi berikutnya berfokus pada manfaat, tantangan dan solusi yang mungkin untuk mendorong integrasi antar kelompok. Solusi yang diusulkan terlibat kontak antar kelompok, memperdalam pengetahuan tentang budaya lain, dan pengakuan atas hak-hak imigran. Solusi ini menunjukkan dewasa muda keterbukaan terhadap imigran dan sikap mereka mengenai integrasi antar budaya.

Setiap media BK yang diaplikasikan di sekolah semuanya menarik bagi siswa, apalagi jika media tersebut menuntut siswa lebih aktif berperan. Hal itu tentu akan semakin menambah ketertarikan tersendiri, termasuk media photovoice. Teknik photovoice memang memiliki keunikan tersendiri dimana anak berperan langsung baik dalam pengambilan gambar maupun menjadi model dalam foto tersebut.

Proses observasi dilakukan melalui dua tahapan. Pertama, penulis melakukan wawancara dengan guru BK pada hari jumat tanggal 05 Agustus 2019 pukul 13:00 terkait media apa saja yang ada dan digunakan di MTs Negeri 1 Kota Cirebon dan apakah disana terdapat media photovoice. Ternyata media photovoice belum diaplikasikan di sekolah tersebut, masih hanya berupa foto yang diberi sedikit narasi kemudian dicetak. Keadaan ini membuat penulis tertarik mengaplikasikan pertama kalinya media photovoice untuk mengurangi perilaku bullying. Penulis memilih tema bullying karena memang di MTs Negeri 1 Kota Cirebon masih marak terjadi perilaku bullying. Guru BK juga sering menerima laporan tentang para siswa yang melakukan aksi bullying baik secara individu maupun kelompok.

Kedua, setelah melakukan wawancara dengan guru BK, penulis dan tim datang lagi ke sekolah pada hari jumat tanggal 28 Agustus 2019 pukul 07:30. Pertemuan kedua ini penulis memanfaatkan waktu untuk memberikan contoh tentang photovoice bertemakan bullying. Dari contoh tersebut para siswa menjadi tahu mengenai tipe-tipe bullying dan dampak dari perilaku bullying. Setelah selesai menjelaskan, para siswa diajak bekerjasama untuk membuat photovoice sendiri.Mereka berperan sebagai model dalam pembuatan photovoice tersebut.

Permasalahan bullying yang sering terjadi di MTs Negeri 1 Kota Cirebon dirasa sudah melampaui batasan karena ada satu jenis bullying yaitu bullying secara verbal yang menjurus kepada saling ejek nama orang tua. Hal ini dirasa tidaklah mencerminkan sikap dan perilaku sebagai seorang pelajar uyang diharapkan. Terlebih dari hasil wawancara penulis kepada siswa-siswi di MTs Negeri 1 Kota Cirebon mereka menyatakan bahwasanya fenomena bullying yang terjadi di sekolah sudah menjadi hal yang biasa dan dianggap sesuatu yang wajar. Hal ini tidak lain disebabkan karena kurangnya pemahaman siswasiswi mengenai bullying secara mendalam. Dibalik kegiatan bullying yang siswa lakukan sebenarnya akan memicu bibit-bibit penyakit baru yang nantinya bisa berdampak pada kondisi mental korban bullying.

Photovoice awalnya dikembangkan pada tahun 1990-an oleh Caroline Wang sebagai bagian dari penelitian tindakan partisipatoris dan penelitian tindakan pertisipasi berbasis umumnya digunakan untuk meneliti perubahan individu dan sosial. Dalam photovoice ini, 
orang diasumsikan sebagai orang yang paling tahu kehidupan dirinya sendiri, artinya dalam photovoice ini menyediakan informasi dengan menyelidiki lebih dalam prespektif tentang topik tertentu. Penggunaan teknik fotografi tertentu mendorong peserta untuk berfikir tentang kekuatan dan kelemahan masyarakat untuk mewakili dan memperbaikinya.

Wang (1999) mendeskripsikan photovoice sebagai metode yang menemukan akarnya dalam masyarakat, didasarkan pada tiga teori, yaitu: 1) pendidikan Freire mengenai teori kesadaran kritis, yang membantu peserta untuk memehami dan bertindak terhadap kondisi sejarah, politik dan sosial sebagai instrumen yang sangat penting untuk perubahan masyarakat; 2) teori Feminist yang sangat menghargai adanya pengalaman subjektif, mengakui makna pemgalaman serta komitmen politis. Dalam menggambarkan ide, Wang mengutip Griselda Pollock yang menyatakan bahwa. "setiap orang memeliki cerita tertentu, sebuah pengalaman khususnya konfigurasi kelas, ras, gender, kualitas, keluarga, negara, perpindahan, aliansi. Cerita mereka dimediasi oleh bentuk-bentuk representasi yang tersedia dalam budaya, Dokumentasi fotografi, sebagian besar digunakan untuk memberikan suara kepada orang-orang yang paling rentan (perempuan, anak-anak, lansia), yang memungkinkan mereka untuk menceritakan kisah dan menjelaskan presepsi mereka mengenai dunia mereka. Sebuah foto bisamenjelaskan berbagai makana.

Photovoice adalah suatu proses yang dapat membantu individu untuk mengidentifikasi, mewakili dan memperkuat komunitas melalui teknik fotografi. Ditangan individu, gambar visual dapat "berbicara" tentang berbagai hal, bersifat fleksibel dan memungkinkan individu utk berpartisipasi aktif dalam komunitas bahkan dengan kekurangan yg ada pada dirinya. Photovoice dapat diaplikasikan diberbagai bidang seperti pendidikan, klinis, sosial, industri, forensik dll.

Photovoice juga merupakan sebuah teknik (terapi, latihan, pengamatan, proses, rehabilitasi) yang dapat membantu individu untuk mengidentifikasi, mewakili dan memperkuat komunikasi melalui gambar atau image atau foto. Metode yang diterapkan adalah riset partisipan, dimana individu mengambil foto untuk membuat orang lain melihat dunia melalui kameranya atau gambar yang dia ambil. Terdapat tiga tujuan utama dari pelaksanaan photovoice yaitu:mencatat dan merekam kelebihan lingkungan di sekitar pasien/klien, memungkinkan adanya dialog dengan bahasan diskusi foto dalam kelompok dan mempengaruhi pengambilan keputusan pasien/klien.

Dalam photovoice, foto berfungsi sebagai pemicu perubahan pola pikir dan perilaku yang diharapkan sebagai tujuan psikoterapi. Foto juga merupakan bentuk dokumentasi sosial yang mewakili pengalaman pribadi dan menyampaikan pengetahuan dari sudut pandang individu. Dalam prosesnya, individu akan diminta untuk menuliskan narasi yang sesuai dengan pemahamannya akan gambar atau foto yang dihadirkan dalam proses diskusi.

Selain untuk kepentingan individu secara individual, photovoice telah digunakan oleh sebuah Badan Internasional di Afrika untuk mengubah sebuah fenomena sosial negatif yang menjangkiti masyarakat, seperti dalam menurunkan angka HIV/AIDS atau 
penyalahgunaan alkohol. Selain itu, hasil penelitian juga menunjukkan keefektifan aplikasi photovoice dalam membantu individu dengan kerusakan otak (brain-injured patient) dalam menyusun strategi untuk daily living. Photovoice bisa diterapkan untuk populasi usia mulai dari kanak-kanak sampai lansia, dan beragam komunitas, seperti komunitas anak jalanan, anak sekolah, transgender, penyandang kebutuhan khusus. Dalam kegiatan photovoice, peserta didorong untuk mengkritisi foto-foto situasi di masyarakat yang berbeda dari mereka dan menjelaskan presepsi mereka terhadap situasi yang memperlihatkan perubahan.

\section{SIMPULAN}

Dari data dan fakta yang telah dipaparkan diatas maka penulis dapat menyimpulkan bahwa penggunaan media photovoice di sekolah diharapkan dapat mempengaruhi pola pikir dan tingkah laku siswa-siswi di sekolah terlebih untuk siswa-siswi MTs Negeri 1 Kota Cirebon. Dalam Photovoice, foto berfungsi sebagai pemicu perubahan pola pikir dan perilaku yang diharapkan sebagai tujuan psikoterapi. Dalam prosesnya, individu akan diminta untuk menuliskan narasi yang sesuai dengan pemahamannya akan gambar dan foto yang dihadirkan dalam proses diskusi. Dengan adanya media tersebut maka siswa-siswi dapat berperan aktif dalam pencegahan hal-hal yang tidak di inginkan seperti bullying di MTs Negeri 1 Kota Cirebon.

Media photovoice sendiri dalam pengaplikasiannya tidak lah sulit, karena hanya alat seperti, foto, laptop/PC (proses editing), dan recording (bagian narasi) di video. Siswasiswi yang mengetahui adanya media ini sangat menerima jika adanya kehadiran photovoice sebagai media informasi yang bermanfaat dan juga memberikan peran aktif siswa-siswi dalam berkreatifitas. Dikarenakan media ini menjadi hal baru bagi MTs Negeri 1 Kota Cirebon maka diharapkan dengan adanya media ini dapat mengubah pola pikir siswa-siswi yang menjadi pelaku bullying di sekolah. Rekomendasi untuk guru BK di MTs Negeri 1 Kota Cirebon maupun sekolah lain hendaknya memberikan sarana kepada siswa siswi di sekolah dalam berperan aktif untuk hal yang positif, seperti media photovoice yang dapat memberikan warna dalam pendidikan di sekolah untuk memberikan pengetahuan dalam berbagai aspek yang berkaitan dengan kepribadian siswa maupun aktivitas sekolah.

\section{DAFTAR PUSTAKA}

Anwar, Moh. Khoerul. (2015). Pengembangan Pribadi Sosial. Diakses tanggal 11 Mei 2018 dari https://khoerulanwarbk.wordpress.com/2015/08/26/pengembanganpribadi-konselor/

Azwar. (1990). Metode Penelitian. Yogyakarta: Pustaka Pelajar.

Bredesen A. Joyce, Marcia S. Stevens. (2013). Using Photovoice Methodology to Give Voice to the Health Care Needs of Homeless Families. Jurnal School of Nursing Metropolian State University, 3 (3). 
Coloroso, Barbara. (2003). The Bully, the Bullied, and the Bystander. New York: Collins Living.

Handoyo, Alfian Warih. (2013). Peningkatan Sensitivitas Gender Dengan Teknik Photovoice Pada Siswa Ekstrakurikuler Fotografi SMAN 11 Yogyakarta. Skripsi. Universitas Negeri Yogyakarta.

Harahap, Faridah. (2015). Teknik-teknik Inovatif Dalam Bimbingan (Guidance) di Sekolah. Yogyakarta: Fakultas Ilmu Pendidikan Universitas Negeri Yogyakarta.

IPK Indonesia Wilayah Jawa Timur. (2012). Introduction to Photovoice (Pertemuan IPKPDSJKI 18/01/12). Dikses tanggal 18 Maret 2018 dari http://ipkjatim.org/2012/01/18/hello-world/

M. Subana dkk. (2011). Dasar-Dasar Penlitian Ilmiah. Bandung: Pustakan Setia.

Made Diah Lestari, Ni Made Dian Sulistiowati, Ni Putu Natalya. (2016). Kesehatan Seksual dan Reproduksi serta Fasilitas kesehatan di Lokasi Prostitusi: Community Based Participatory Research dengan Photovoice Pada Pekerja Seksual di Gunung Lawu, Bali. Jurnal Psikologi Universitas Diponegoro 15 (1).

Nasution. (2003). Metode Penelitian. Jakarta: Bumi Aksara.

Pawito. (2007). Penelitian Komunikasi Kualitatif. Yogyakarta: LKIS.

Rania, Nadia, dkk. (2015). Dare Un Volto Ai Processi di Immigrazione e Integrazione: I'Uso di fotovoice Con I Giovani Adulti Italiani. Jurnal University of Genoa 20 (6).

Suharsimi Arikunto. (1996). Prosedur Penelitian Suatu Pendekatan Praktek. Jakarta: PT. Rineka Cipta.

Sulistyo, Basuki. (2006). Metode Penelitian. Jakarta: Wedatama Widya Sastra dan Fakultas Ilmu Pengetahuan Budaya Universitas Indonesia.

Ulviatun, Ernie. (2016). Upaya Peningkatan Sikap Empati Melalui Teknik Photovoice Pada Siswa Kelas X Jurusan Kriya Kulit di SMK Negeri 1 Kalasan. Skripsi. Universitas Negeri Yogyakarta. 
212 | Zulpikar - Media Photovoice untuk ... 